\title{
Relationship between The Amount of Available $P$ and Manure Application by Calcareous Soils
}

\author{
Said Abbas Mohamed EL-Sayed ${ }^{1}$
}

\begin{abstract}
The objectives of this study were to measure the residual $\mathrm{NaHCO}_{3}$-extractable $\mathrm{P}$ resulting from manure applications at high rates and to contrast the $\mathrm{NaHCO}_{3}{ }^{-}$ exractable $P$ levels for manure vs inorganic $P$ fertilizers.

When inorganic $P$ was applied annually at a rate of 206 $\mathrm{kg} /$ Feddan at the $(0$ to $30 \mathrm{~cm})$ depth of 2 years, the $\mathrm{NaHCO}_{3}$-extractable $\mathrm{P}$ was increased from 17 to $32 \mathrm{ppm}$ in soil . The application of $42 \mathrm{~kg} /$ Feddan annually of $P$ as triple superphosphate of 2 years before planting spinach (September-October) was effective for increasing $\mathrm{NaHCO3}$ extractable $P$ during the spinach-growing season (November, 2011) as applying $206 \mathrm{~kg} /$ Feddan of $P$ in May or June each of 2 years.

High rates of $P(2245 \mathrm{~kg} / \mathrm{Feddan})$ applied from manure resulted in high levels of $\mathrm{NaHCO}_{3}$,-extractable $\mathrm{P}$ up to 378 ppm. Total application of more than 152 tons/Feddan of manure $(1123 \mathrm{~kg} P /$ Feddan) resulted in movement of $P$ in soil $(30$ to $60 \mathrm{~cm})$. The increased level of $\mathrm{NaHCO}_{3}$,Extractable $P$ from a manure application (treatment 152 B) was still evident in the 0 to $30 \mathrm{~cm}$ depth , 6 years after manure application had ceased.
\end{abstract}

The application of $165 \mathrm{~kg}$ P/Feddan as triple superphosphate for each of 2 years increased the $\mathrm{NaHCO}_{3}-$ extractabl $P$ over the control by 12 ppm (November, 2011).In comparing, the application of $141 \mathrm{~kg} P / F e d d a n$ from applied manure each of 2 years increased the $\mathrm{NaHCO}_{3}$-extractable $\mathrm{P}$ over the control (after harvest in 2007) by 101 ppm.

Key words: Organic phosphorus, nutrient movement, $\mathrm{NaHCO}_{3}$-extractable $\mathrm{P}$.

\section{INTRODUCTION}

In recent years, the amount of manure generated at large feedlots on small areas of land has increased. Manure has become a liability in many areas instead of an asset because feedlot operators must pay for its removal. The cost and energy involved in commercial fertilizer production, however, makes it imperative that utilize manure as a fertilizer.

Comparatively little is known about the long-term effects of applying large amounts of manure to irrigated desert soils. Meek et al. (1974) studied the effect of large applications of manure on the movement of nitrate and carbon in irrigated desert soil. This manuscript summarizes changes in available $\mathrm{NaHCO}_{3}$ - extractable phosphorus $(\mathrm{P})$ caused by large applications of manure to calcareous soils.

Several researchers have reported that manure increases the $\mathrm{NaHCO}_{3}$ - extractable $\mathrm{P}$ in calcareous soils and that this increase may persist for many years after manure applications have stopped. In a field experiment , Abbot and Tucker (1973) measured an increase in $\mathrm{NaHCO}_{3}$-extractable $\mathrm{P}$ in December 1968 from an application of 22 metric tons/ha of manure in 1965 and again in 1967 but detected no increase in 1968 when 22 metric tons/ha of manure was applied in 1965 only. Olsen et al. (1954 a and b) in a greenhouse experiment found that application of 27 metric tons/ha of manure each year from 1912 to 1950 increased the $\mathrm{NaHCO}_{3}$ extractable $\mathrm{P}$, compared to the control , by $64 \mathrm{ppm}$ and $122 \mathrm{ppm}$ for two calcareous soils. Pratt et al. (1956) in a field experiment measured an increase in $\mathrm{NaHCO}_{3}$ extractable P (1927-1955) from 6 to $69 \mathrm{ppm}$ when manure was applied at the rate of 19 metric tons/ha from 1927 to 1939, and 57 metric tons/ha from 1939 to 1955. Abbot and Tucker (1973) found that manure applied in 1965 and 1967 increased the P uptake by alfalfa 35\% over the control in 1970 but they did not measure $\mathrm{NaHCO}_{3}$ extractable $\mathrm{P}$ levels in the soil.

Organic matter (especially manure) increases the movement of $\mathrm{P}$ whereas application of inorganic fertilizer generally does not increase its movement (Hannapel et al., $1964 \mathrm{a}$ and b; and Rolston et al., 1975; EI-Sayed, 2003; EL-Sayed et al., 2001 (a and b) and ELSayed, 2002 (a ,b and c). Hannapel et al. (1964 b) found that Organic matter increased $\mathrm{P}$ movement in calcareous soils, and they suggested that this movement was associated with movement of microbial cells and cellular debris. Rolston et al. (1975) found that organic phosphate compounds may be moved greater distance's into soil than is possible with inorganic phosphates. Singh and Jones (1976) found that poultry manure increased $\mathrm{P}$ in solution and decreased its sorption by the soil.

Field and greenhouse studies have been utilized to evaluate the effect of long term-low rate manure applications on $\mathrm{NaHCO}_{3}$-extractable $\mathrm{P}$ in calcareous soils (Olsen et al., 1954 a and b; Pratt et al., 1956; ELSayed, 1995 (a, b, c and d) and EL-Sayed, 1999). Other field studies have measured the effect of manure applications at high rates of $\mathrm{NaHCO}_{3}$-extractable $\mathrm{P}$ in

\footnotetext{
${ }^{1}$ Department of Soil and Water Science, Faculty of Agriculture, Al-Azhar University,Assiut ,Egypt.

Received November 6, 2013, Accepted December 5, 2013
} 
calcareous soils, but studies were conducted for only a few years.

The objectives of these study were to: (i) evalue the effect of monitor for 6 years with the residual $\mathrm{NaHCO}_{3}$ extractable $\mathrm{P}$ content resulting from manure applications at high rates and (ii) compare the $\mathrm{NaHCO}_{3}$-extractable $\mathrm{P}$ levels for manure vs. inorganic $\mathrm{P}$ fertilizers.

\section{MATERIALS AND METHODS}

The study was conducted on a calcareous soil at Nubaria Agriculture Research Station, at Alexandria, from 2000 to 2012.The soil is classified as a Typic Torrifluvent, hyperthermic family according to Soil Survey Staff (1994), and the top $30 \mathrm{~cm}$ of soil contained $1.1 \%$ organic matter, saturated soil paste were $7.9 \mathrm{pH} ; 12 \% \mathrm{CaCO}_{3}$; and it had a cation exchange capacity of $25 \mathrm{meq} / 100 \mathrm{~g}$. The soil texture was clay in the $(0$ to $30 \mathrm{~cm})$ depth, silty clay loam in the $(30$ to 90 $\mathrm{cm})$ depth and silt loam in the $(90$ to $150 \mathrm{~cm})$ depth. The clay fraction was mainly montmorillonite. The infiltration rate of the soil was about $0.19 \mathrm{~cm} / \mathrm{hr}$ under saturated conditions (Page et al., 1982). Plots were 12.3 by $12.3 \mathrm{~m}$ and a distance of $6.2 \mathrm{~m}$ was maintained between plots.

Manure was applied in January or February for 10 years (2000-2009) with total application rates ranging from 0 to 303 tons /Feddan, as indicated in Table (1). The average composition of the manure, on an oven-dry basis, was; $17.6 \%$ water, $2.4 \%$ total $\mathrm{N}, 0.8 \% \mathrm{P}, 58.5 \%$ organic matter, $1.2 \% \mathrm{Na}$, and $2.2 \% \mathrm{~K}$. An application of 76 tons/ Feddan of manure (17.6\% water) would contain $562 \mathrm{~kg} \mathrm{P} /$ Feddan. Each plot was divided into ( 6 to 9) subplots, then the correct amount of manure was added and mixed uniformly using a shovel and rake. Each treatment was replicated four times (Steel and Terrie, 1982 and SAS, 1988).
The plots were cropped each year except 2012, when the field was left fallow for watergrass control. All crops were adequately fertilized with $\mathrm{N}$. Phosphorus fertilizer is applied to vegetable crops at Nubaria Agriculture Research Station, but not to sorghum. There was a reduction in yield of sorghum (Sorghum biclor L.Moench) when manure was applied at yearly rates of 152 tons/ Feddan .In 2007, only P fertilizer was applied to all plots of spinach at a rate of $56 \mathrm{~kg}$ P/ Feddan in (2000, 2007, 2008, 2009, and 2010). Sorghum (Sorghum bicolor L. Moench) variety Giza 113 was planted in March or April and harvested in August. Spinach (Spinacia oleracea L.) was planted in the field in October 2007 and 2011 and harvested in January of the following year. In 2011 barely (Hordeum vulgare L) variety Giza 124 was planted in January and harvested in May.

Soil samples were taken ( 0 to $30 \mathrm{~cm}$ and 30 to $60 \mathrm{~cm}$ ) depths at the beginning of the experiment and each year after harvest. Analyses were conducted on a composite soil sample from each plot and each depth which consisted of three cores in 2000 and 2007 and eight cores in (2008-2012).

To determine the $\mathrm{P}$ moving in the soil, solution samples were collected with ceramic cups during one irrigation in 2009 by the procedure used by Meek et al. (1974). One sample was collected at each of the four depths $(30,60,90$ and $150 \mathrm{~cm})$ from three plots $(0,152$ Band $303 \mathrm{E}$ treatments). An aliquot of the sample was digested with persulfate solution (American Public Health Association, 1976) before analysis to release organically bound $\mathrm{P}$.

A supplemental study was conducted in a field of the same soil type (saturated soil paste of $7.9 \mathrm{pH}, 12 \%$ $\mathrm{CaCO}_{3}$ ) located about $0.6 \mathrm{~km}$ from the main field. Initially, this field contained approximately one-half the $\mathrm{NaHCO}_{3}$ - extractable $\mathrm{P}$ of the manured field (6 ppm compared to $10 \mathrm{ppm})$.

Table 1. Manure treatments at different years

\begin{tabular}{lccccc}
\hline $\begin{array}{l}\text { Treatment } \\
\text { code* }\end{array}$ & $\begin{array}{l}\text { P applied } \\
\text { kg/feddan }\end{array}$ & $\mathbf{2 0 0 0}$ & $\mathbf{2 0 0 7}$ & $\mathbf{2 0 0 8}$ & $\mathbf{2 0 0 9}$ \\
\hline 0A & 0 & 0 & 0 & 0 & 0 \\
\hline $76 \mathrm{~B}$ & 562 & 76 & 0 & 0 & 0 \\
\hline $76 \mathrm{E}$ & 562 & 19 & 19 & 19 & 19 \\
\hline $114 \mathrm{D}$ & 842 & 38 & 38 & 38 & 0 \\
\hline $152 \mathrm{~B}$ & 1123 & 152 & 0 & 0 & 0 \\
\hline $227 \mathrm{C}$ & 1684 & 76 & 152 & 0 & 0 \\
\hline $227 \mathrm{D}$ & 1684 & 76 & 76 & 76 & 0 \\
\hline $303 \mathrm{E}$ & 2245 & 76 & 76 & 76 & $76^{* *}$ \\
\hline
\end{tabular}

* Total manure application (2000-2009), in tons per Feddan for $\mathrm{A}=0, \mathrm{~B}=\mathrm{I}, \mathrm{C}=2, \mathrm{D}=3$, and $\mathrm{E}=4$ applications.

**This treatment was split in 2009 so data are based on two plot values instead of four from 2009. 
Triple superphosphate was broadcasted at rates of 0 , $42,83,124,165$ and $206 \mathrm{~kg}$ /feddan to plots $12.3 \mathrm{~m}$ square in May of 2010 and June 2011.After the fertilizer was applied, the plots were irrigated three times during the summer and not cropped. The field was prepared and spinach (Spinacia oleracea L.) was planted in October 2010 and September 2011and adequately fertilized with $\mathrm{N}$. In one treatment, $42 \mathrm{~kg}$ P/Feddan was applied in the fall (instead of May or June) just before planting the spinach. Each treatment was replicated six times. Soil samples (0 to 30 and 30 to $60 \mathrm{~cm}$ ) depths were taken in August 2010, April and November of 2011, and January 2012. Eight soil cores were taken from each plot and one composite sample from each plot at each depth was analyzed.

The colorimetric ascorbic acid method (Watanabe and Olsen, 1965) was used to measure $\mathrm{P}$ in $\mathrm{NaHCO}_{3}$ extracts (Olsen et al.,1954 a and b), and in soil solutions. Procedures in the salinity handbook (U.S. Salinity Laboratory Staff., 1954) were used to determine $\mathrm{CaCO}_{3}$ (by gravimetric loss of $\mathrm{CO}_{2}$ ), organic matter, and cation exchange capacity.

\section{RESULTS and Discussion}

$\mathrm{NaHCO}_{3}$-extractable $\mathrm{P}$ at the $(0$ to $30 \mathrm{~cm})$ depth after inorganic fertilizer applications:

The application of high rates of inorganic $\mathrm{P}$ fertilizer resulted in small increases in $\mathrm{NaHCO}_{3}$-extractable $\mathrm{P}$ (Table 2). The $\mathrm{P}$ level in the soil $(0-30 \mathrm{~cm})$ was $32 \mathrm{ppm}$ or less even when $206 \mathrm{~kg}$ P/Feddan was applied annually of 2 years. Inorganic $\mathrm{P}$ applied in the summer of 2010 was fixed rapidly sand there were only small increases in $\mathrm{NaHCO}_{3}$-extractable $\mathrm{P}$ in August of 2010 from treatments applied in May 2010.The applying of $165 \mathrm{~kg} /$ feddan or more in May to significantly increase NaHCO3-extractable P in August as compared with the control (EL-Sayed and Salem, 2001). As much or more $\mathrm{NaHCO}_{3}$-extractable $\mathrm{P}$ was present in November 2011 from application of $42 \mathrm{~kg} \mathrm{P} /$ Feddan just before planting as from $206 \mathrm{~kg} \mathrm{P} /$ Feddan which applied 4 or 5 months earlier (Ahmad and EL-Sayed, 2002 and EL-Sayed, 1989 and 2001).

Available $P$ at the $(0$ to $30 \mathrm{~cm})$ depth after manure applications:

The application of manure caused large increases in the amount of $\mathrm{NaHCO}_{3}$-extractable $\mathrm{P}$ (Table 3).In the control, the soil $(0-30 \mathrm{~cm})$ contained (10-28) ppm $\mathrm{NaHCO}_{3}$-extractable $\mathrm{P}$ (2007-2012). The large variation between years was probably different amounts of crop residues due to the different sampling times (EL-Sayed and Ahmad, 2001). In contrast to the control treatment, some of the manure treatments contained $\mathrm{NaHCO}_{3}{ }^{-}$ extractable $\mathrm{P}$ up to $378 \mathrm{ppm}$. Manure affected $\mathrm{NaHCO}_{3^{-}}$ extractable $\mathrm{P}$ for several years; for, example, treatment $152 \mathrm{~B}$ (1123 kg P/Feddan), a plot that received manure only in 2000, still had about seven times more $\mathrm{NaHCO}_{3}$ extractable $\mathrm{P}$ than the control in 2012. After manure applications had ceased, $\mathrm{NaHCO}_{3}$-extractable $\mathrm{P}$ from application of manure decreased about $15 \%$ each year. The application of 76 tons/Feddan in 2000 only (76 B) or the application of 19 tons/Feddan for 4 years (76 B), resulted in the same $\mathrm{NaHCO}_{3}$-extractable $\mathrm{P}$ level in 2012. This was also true of treatments $227 \mathrm{C}$ and $227 \mathrm{D}$ (EL-Sayed, 1995 a,b,c and d and EL-Keiy and ELSayed, 1991).

$\mathrm{NaHCO}_{3}$-extractable $\mathrm{P}$ at the $(30$ to $60 \mathrm{~cm})$ depth after manure applications:

Manure applications increased the $\mathrm{NaHCO}_{3}-$ extractable $\mathrm{P}$ in soil $(30$ to $60 \mathrm{~cm}$ ) as shown in Table 4 .The control plots contained 2-8 ppm $\mathrm{NaHCO}_{3^{-}}$ extractable $\mathrm{P}$, whereas the highest rate of manure application increased the $\mathrm{P}$ level to $44 \mathrm{ppm}$. By 2012, there was no difference in $\mathrm{NaHCO}_{3}$-extractable $\mathrm{P}$ between the check and treatments of less than 227 tons/Feddan (1684 kg P/Feddan).

Table 2. $\mathrm{NaHCO}_{3}$-extractable $\mathrm{P}$ in soil $(0-30 \mathrm{~cm})$ samples taken from plots treated with triple superphosphate fertilizer

\begin{tabular}{lccccc}
\hline P applied kg/Feddan & \multicolumn{4}{l}{ NaHCO $_{\mathbf{3}^{-}}$extractable P,ppm } \\
\hline $\mathbf{2 0 1 0}$ & $\mathbf{2 0 1 1}$ & August2010 & April2011 & November2011 & January2012 \\
\hline 0 (May) & 0 (June) & $6 \mathrm{a}^{*}$ & $11 \mathrm{a}$ & $17 \mathrm{a}$ & $15 \mathrm{a}$ \\
\hline 42 (May) & 42 (June) & $8 \mathrm{ab}$ & $13 \mathrm{ab}$ & $23 \mathrm{bc}$ & $20 \mathrm{ab}$ \\
\hline 83 (May) & 83 (June) & $9 \mathrm{abe}$ & $15 \mathrm{bc}$ & $25 \mathrm{bc}$ & $24 \mathrm{bc}$ \\
\hline 165 (May) & 165 (June) & $10 \mathrm{be}$ & $15 \mathrm{abc}$ & $28 \mathrm{~cd}$ & $27 \mathrm{c}$ \\
\hline 206 (May) & 206 (June) & $12 \mathrm{~cd}$ & $17 \mathrm{c}$ & $32 \mathrm{~d}$ & $30 \mathrm{c}$ \\
\hline 42 (October) & 42 (September) & $7 \mathrm{ab}^{* *}$ & $26 \mathrm{~d}$ & $32 \mathrm{~d}$ & $24 \mathrm{bc}$ \\
\hline
\end{tabular}

* Column values within years followed by same letter are not significantly different at the $5 \%$ level.

** No P fertilizer had been applied at this date. 
Table 3. The amounts of $\mathrm{NaHCO}_{3}$-extractable $\mathrm{P}$ from soil $(0-30 \mathrm{~cm})$ depth in soil samples taken from manure-treated plots after harvest

\begin{tabular}{lccccccc}
\hline Treatment & $\begin{array}{c}\text { P applied } \\
\text { code** }\end{array}$ & \multicolumn{7}{c}{ NaHCO $_{\mathbf{3}^{-}}$extractable P,ppm } \\
\cline { 2 - 8 } & $\mathbf{k g}$ /Feddan & $\mathbf{2 0 0 7}$ & $\mathbf{2 0 0 8}$ & $\mathbf{2 0 0 9}$ & $\mathbf{2 0 1 0}$ & $\mathbf{2 0 1 1}$ & $\mathbf{2 0 1 2}$ \\
\hline $0 \mathrm{~A}$ & 0 & $10 \mathrm{a}^{*}$ & $22 \mathrm{a}$ & $10 \mathrm{a}$ & $18 \mathrm{a}$ & $28 \mathrm{a}$ & $15 \mathrm{a}$ \\
$76 \mathrm{~B}$ & 562 & $110 \mathrm{c}$ & $107 \mathrm{~b}$ & $70 \mathrm{bc}$ & $61 \mathrm{~b}$ & $70 \mathrm{~b}$ & $54 \mathrm{~b}$ \\
$76 \mathrm{E}$ & 562 & $68 \mathrm{abc}$ & $102 \mathrm{~b}$ & $99 \mathrm{~cd}$ & $109 \mathrm{c}$ & $69 \mathrm{~b}$ & $59 \mathrm{~b}$ \\
$114 \mathrm{D}$ & 842 & $91 \mathrm{bc}$ & $173 \mathrm{c}$ & $123 \mathrm{~d}$ & $137 \mathrm{c}$ & $89 \mathrm{c}$ & $72 \mathrm{~b}$ \\
$152 \mathrm{~B}$ & 1123 & $194 \mathrm{~d}$ & $190 \mathrm{c}$ & $121 \mathrm{~d}$ & $124 \mathrm{c}$ & $104 \mathrm{c}$ & $95 \mathrm{c}$ \\
$227 \mathrm{C}$ & 1684 & $316 \mathrm{e}$ & $275 \mathrm{~d}$ & $196 \mathrm{e}$ & $216 \mathrm{~d}$ & $116 \mathrm{~d}$ & $145 \mathrm{~d}$ \\
$227 \mathrm{D}$ & 1684 & $197 \mathrm{~d}$ & $264 \mathrm{~d}$ & $239 \mathrm{f}$ & $230 \mathrm{~d}$ & $174 \mathrm{e}$ & $146 \mathrm{~d}$ \\
$303 \mathrm{E}^{* * *}$ & 2245 & $298 \mathrm{e}$ & $285 \mathrm{~d}$ & $278 \mathrm{~g}$ & $359 \mathrm{e}$ & $255 \mathrm{f}$ & $238 \mathrm{e}$ \\
\hline
\end{tabular}

*Column values within years followed by same letter are not significantly different at the $5 \%$ level.

**Total manure application (2000-2009) ; in tons per Feddan for $\mathrm{A}=0, \mathrm{~B}=1, \mathrm{C}=2, \mathrm{D}=3$ and $\mathrm{E}=4$ applications.

*** This treatment was split in 2009 so data are based on two plot values instead of four from 2009.

Table 4. $\mathrm{NaHCO}_{3}$-extractable $\mathrm{P}$ from soil $(30-60 \mathrm{~cm})$, samples taken from manure-treated plots after harvest

\begin{tabular}{lccccc} 
Treatment code** & $\begin{array}{c}\text { P.applied } \\
\text { kg/Feddan }\end{array}$ & \multicolumn{4}{c}{ NaHCO3-extractable P. ppm } \\
\cline { 2 - 5 } & 0 & $\mathbf{2 0 0 9}$ & $\mathbf{2 0 1 0}$ & $\mathbf{2 0 1 1}$ & $\mathbf{2 0 1 2}$ \\
\hline 0A & 562 & $4 \mathrm{a}^{*}$ & $5 \mathrm{a}$ & $2 \mathrm{a}$ & $8 \mathrm{a}$ \\
$76 \mathrm{~B}$ & 562 & $5 \mathrm{a}$ & $6 \mathrm{ab}$ & $4 \mathrm{ab}$ & $11 \mathrm{a}$ \\
$76 \mathrm{E}$ & 842 & $6 \mathrm{ab}$ & $8 \mathrm{ab}$ & $3 \mathrm{ab}$ & $10 \mathrm{a}$ \\
114D & 1123 & $8 \mathrm{bc}$ & $8 \mathrm{ab}$ & $4 \mathrm{ab}$ & $15 \mathrm{a}$ \\
$152 \mathrm{~B}$ & 1684 & $11 \mathrm{~cd}$ & $9 \mathrm{~b}$ & $5 \mathrm{ab}$ & $16 \mathrm{a}$ \\
227C & 1684 & $13 \mathrm{~d}$ & $17 \mathrm{c}$ & $7 \mathrm{~b}$ & $40 \mathrm{bc}$ \\
$227 \mathrm{D}$ & 2245 & $16 \mathrm{c}$ & $16 \mathrm{c}$ & $12 \mathrm{c}$ & $32 \mathrm{~b}$ \\
$303 \mathrm{E}^{* * *}$ & & $14 \mathrm{c}$ & $44 \mathrm{c}$ \\
\hline
\end{tabular}

* Column values within years followed by same letter are not significantly different at the 5\% level.

**Total manure application (2000-2009) in tons per Feddan for $\mathrm{A}=0, \mathrm{~B}=], \mathrm{C}=2, \mathrm{D}=3$, and $\mathrm{E}=4$ applications.

*** This treatment was split in 2009 so data are based on two plot values instead of four From 2009.

Plots Treated with 227 tons/Feddan or more had large increases in $\mathrm{NaHCO}_{3}$-extractable P from 2011 to 2012. However, the application of inorganic $\mathrm{P}$ fertilizer did not increase $\mathrm{NaHCO}_{3}$-extractable $\mathrm{P}$ at the 30 to $60 \mathrm{~cm}$ soil depth (Faragallah and EL-Sayed, 2002, Fatma et al., 2013).

\section{$P$ contents of soil solutions:}

Manure applications increased the $\mathrm{P}$ content of soil solutions (Table 5). Soluble $\mathrm{P}$ content of the soil solutions in the check and $152 \mathrm{~B}$ treatments was generally low. The highest manure application increased the P level between the 30 and $150 \mathrm{~cm}$ depths. Similar values for the persulfate digested samples and the undigested samples indicated that the $\mathrm{P}$ moved in a soluble organic or inorganic form and not as part of a complex organic carbon compound. The persulfate digestion would have been expected to break down the complex organic compounds and release $\mathrm{P}$ in a soluble form (EL-Sayed, 2002 a, b and c and Ghaly and ELSayed, 1997).
Manure applications increased $\mathrm{NaHCO}_{3}$ - extractable soil $\mathrm{P}$ to high levels in the 0 to $30 \mathrm{~cm}$ depth and maintained the $\mathrm{P}$ above $51 \mathrm{ppm}$ for 6 years without additional manure applications. In addition, manure caused $\mathrm{P}$ movement and an increasing in $\mathrm{NaHCO}_{3}$ extractable $\mathrm{P}$ at the $(30$ to $60 \mathrm{~cm}$ ) depth. Analysis of soil solution samples indicated that the $\mathrm{P}$ was moving in the soil solution (EL-Sayed et al., $2001 \mathrm{a}$ and b and AbdelMawly and EL-Sayed, 1999). These data indicated that $\mathrm{NaHCO}_{3}$-extractable $\mathrm{P}$ remained higher from manure applications than from applications of inorganic phosphorus fertilizer when $\mathrm{P}$ application rates were similar (EL-Sayed,2003). When $141 \mathrm{~kg} \mathrm{P}$ was applied in the manure (19 tons /Feddan per year) in 2000 and 2007, the amount of $\mathrm{NaHCO}_{3}$-extractable $\mathrm{P}$ was $68 \mathrm{ppm}$ after harvest in August of 2007.

When $165 \mathrm{P} /$ Feddan were applied as triple superphosphate in 2010 and 2011, the $\mathrm{NaHCO}_{3}$ extractable $\mathrm{P}$ concentration was $28 \mathrm{ppm}$ in November 2011. 
Table 5. Soluble $P$ collected using ceramic cups in 2009

\begin{tabular}{cccc}
\hline \multirow{2}{*}{ Treatment code* } & Depth & \multicolumn{2}{c}{ P .ppm } \\
\cline { 3 - 4 } cm & Soil solution & Persulfate-digested Soil solution \\
\hline OA & 30 & 0.3 & 0.2 \\
& 60 & 0.2 & 0.2 \\
& 90 & 0.2 & 0.2 \\
150 & 0.2 & 0.0 \\
\hline \multirow{2}{*}{ 152B } & 30 & 2.1 & 2.1 \\
& 60 & 0.2 & 0.2 \\
& 90 & 0.2 & 0.0 \\
& 150 & 0.4 & 0.3 \\
\hline \multirow{2}{*}{$303 \mathrm{E}$} & 30 & 14.3 & 13.3 \\
& 60 & 5.1 & 3.4 \\
& 90 & 3.6 & 3.3 \\
\hline
\end{tabular}

* Total manure application (2000-2009); in tons per Feddan for $\mathrm{A}=0, \mathrm{~B}=\mathrm{I}$, and $\mathrm{E}=4$ applications.

In many areas, it would cost less to apply manure at the rate of 19 tons/Feddan for each of 4 years and did not apply $\mathrm{P}$ for the next 4 years than the current fertilizer practice which is to apply $\mathrm{P}$ feltilizer at the rate of $47 \mathrm{~kg}$ P/Feddan each year for winter crops. In2013 at Nubaria Agriculture Research Station at Alexandria, applying the manure (76 tons/Feddan with $7 \mathrm{~km}$ of the feedlot) would cost low pounds as compared with pounds for applying $47 \mathrm{~kg}$ P/Feddan per year for 8 years (low pounds $/ \mathrm{kg}$ of $\mathrm{P})$. In addition, the manure would supply $\mathrm{N}$ to the crops for at least 4 of the 8 years (EL-Sayed, $1998 \mathrm{a}$ and b; 1996; 1997 and 1999; Ahmed, 2013).

\section{CONCLUSIONS}

The application of 19 tons / Feddan of manure per year for 4 years will not usually result in a salinity problem in 'the desert for spinach because the manure can be applied in the spring and leaching can take place during summer.

If manure is applied for many years, then at some time the fixing capacity of the soil should be satisfied, but, at Nubaria Agriculture Research Station at Alexandria with soil containing $11-16 \% \mathrm{CaCO}_{3}$ this may require many years.

\section{REFERENCES}

Abbot, J.L. and T.C. Tucker (973). Persistence of manure phosphorus in calcareous soil. Soil Sci. Soc. Am. Proc. 37: 60-63.

Abdel-Mawly, S.E. and S.A.M. EL-Sayed (1999). Relationship between soil alkalinity and zinc deficiency of maize plants grown on sodic soil. Egypt. J. Appl. Sci.,14 (8): 304-318.
Ahmad, M.A. and S.A.M. EL-Sayed (2002). Effects of some macro elements on growth of tomato (Lycopersicon esculentum Mill) under sodium chloride stress. Proc. Minia, 1st Conf. for Agric. \& Environ. Sci., Minia, Egypt, March 25-28, 2002. PP.593-608.

Ahmed Y.Habel. 2013. Prediction soil bulk density and moisture constants using particle size distribution for selected Libyan calcareous soils. Alex. Sci. Exch. Jour.34 (1):63-70.

American Public Health Association(1976). Standard methods for the examination of water and wastewater. $14^{\text {th }}$ ed. APHA, Washington, D.C.

EL-Keiy, O.M.Z. and S.A.M. EL-Sayed (1991). The effect of phosphorus on biological nitrogen fixation of some forage legumes. J. Agric. Sci. Mansoura Univ., 16 (9): 21792185.

EL-Sayed, S.A.M. (1989). The effect of increasing phosphorus concentration in sand culture on nodulation, growth and biological nitrogen fixation by legumes. Ph.D. Thesis, Faculty of Agric., Alexandria Univ., Egypt.

EL-Sayed, S.A.M. (1995a). Identification' of rhizobacteria from forage sorghum and appraise their plant-growth promoting activity. J. Agric. Sci. Mansoura Univ., 20 (1): 441-451.

EL-Sayed, S.A.M. (1995b). Manure decomposition during aerobic and anaerobic condition. Menofiya J. Agric. Res., 20 (2): 777-788.

EL-Sayed, S.A.M. (1995c). Alkali soil amended with farmyard-manure and pyrite. Menofiya J. Agric. Res., 20 (2): 827-840.

EL-Sayed, S.A.M. (1995d). Sewage sludge as a phosphorus amendment in Egyptian soils. Second conference on-farm irrigation and agro climatology. Organized by Soil, Water \& Environment Research Institute. Agricultural Research Center. 2-4 January 1995. Paper No.44: 653-667. Giza, Egypt. 
EL-Sayed, S.A.M. (1996). Responses of guar to applications of $\mathrm{P}$ and $\mathrm{Fe}$ in calcareous soils. J. Agric. Sci. Mansoura Univ., 21 (7): 2709-2719.

EL-Sayed, S.A.M. (1997). Influence of salinity on growth, yield, nutrient uptake and biological nitrogen fixation in guar. Egypt. J. Agric. Res., 75 (1):1-14.

EL-Sayed, S.A.M. (1998a). Use of sewage sludge and farmyard-manure as N-fertilizer in New Valley Governorate. Egypt .J. Soil Sci., 38 (1-4): 1-19.

EL-Sayed, S.A.M. (1998b). Influence of biofertilization with rhizobium and phosphate solubilizing bacteria on nutrient uptake and yield of lentil. Egypt. J. Microbiol. 33 (1): 61 71.

EL-Sayed, S.A.M. (1999). Relationship between phosphorus additions and nitrogen accumulation by guar. Egypt. J. Soil Sci., 39 (1): 71-84.

EL-Sayed, S.A.M. (2001). Effect of inorganic and organic sources of phosphorus on growth and phosphorus uptake in pigeonpea Cajanus cajan L. Millsp. Alex. Sci. Exch. J , 22 (3): 285-299.

EL-Sayed, S.A.M. (2002a). Relationship between mycorrhizae and uptake of some elements in corn and guar. Assiut. Univ. Bull. Environ. Res., 5 (2): 17-28.

EL-Sayed, S.A.M. (2002b). Effectiveness of some nitrification inhibitors in soils amended with sewagesludge compost .Inter. Conf. For Develop. and The Environ. In The Arab World, March 26-28, 2002. Assiut Univ. Center For Environ. Studies - Egypt. PP.223-236.

EL-Sayed, S.A.M. (2002c). Chemical composition of fulvic acids extracted from sewage sludge-soil mixtures. The First Conf. of The Central Agric. Pesticide Lab., 3-5 Sept., 2002. Vol. (I). PP.231-245.

EL-Sayed, S.A.M. (2003) Effect of EDDHA amendment to soil on P solubility and availability by mycorrhizal guar plant. Alex. Sci. Exch., 24(1): I - 18.

EL-Sayed, S.A.M.; A.S.A. Abdel-Mawgoud; S.A.M. Hegab and M.H.E. Salem (2001 a). Soil salinity and nitrification inhibitor in barley plant. Egypt. J. Soil Sci., 41 (4): 539550.

EL-Sayed, S.A.M.; M. Abo-EI-Wafa and H.A.I. Salem (2001b). salinity-calcium interaction in wheat and barley plants. 1. Agric. Sci. Mansoura Univ., 26 (I): 6607-6621.

EL-Sayed, S.A.M. and M.E. Ahmad (2001). Implications of some bean (Phaseolus vulgaris L.) Varieties to irrigation with sodium chloride. Al-Azhar J. Agric. Res., 33 (June): 305-328.

EL-Sayed, S.A.M. and H.A.I. Salem (2001). Effect of P application on uptake of some micronutrients by rice plants. Alex. Sci. Exch., 22 (3): 255-266.

Faragallah, M.A. and S.A.M. El-Sayed (2002). Relationship between gross changes in soil applied chelates and soil properties. The 3rd Scientific Conf of Agric Sci., Asiut. October 20-22,2002. PP533-545.
Fatma K. Sherif; H.A El-Attar and Hoda A.Argaa.2013. Monitoring P efficiencies and Corn yield by VAM and sulfur application in calcareous soils Alex. Sci. Exch. Jour. 34:(1):44-54.

Ghaly, A.A. and S.A.M. El-Sayed(1997).Effect of soil sodicity on growth, yield, chlorophyll and some biochemical parameters in guar. J. Agric. Sci. Mansoura Univ., 22 (4): 1187-1195 .

Hannapel, R.J.; W. H. Fuller; Shirley Basma and J S. Bullock (1964a). Phosphorus movement in a calcareous soil. 1Predominance of organic forms of phosphorus in phosphorus movement. Soil Sci., 97: 350-357.

Hannapel, R.J.; W.H. Fuller and R.H. Fox (1964b). Phosphorus movement in a calcareous soil. II- Soil microbial activity and organic phosphorus movement. Soil Sci. 97: 421-427.

Meek, B.D.; A.J. Mackenzie; T.J. Donovan and W.F. Spencer (1 974). The effect of large applications of manure on movement of nitrate and carbon in an irrigated desert soil. J. Environ. Qual. 3: 253-258.

Olsen, S.R.; C. V. Cole; F.S. Watanabe and L.A. Dean (1954a). Estimation of available phosphorus in soils by extraction with sodium carbonate. USDA Circ. 939.

Olsen, S.R. Watanabe; H.S. Cosper; W.E. Larson and L.B. Nelson (1954b). Residual phosphorus availability in longtime rotations on calcareous soils. Soil Sci., 78: 141 - 151.

Page, A.L.; R.H. Miller and D.R. Keeney (1982). Methods of soil analysis, Part 2: Chemical and microbiological properties. Amer. Soc. Agron., Madison, Wisconsin, USA.

Pratt, P.F.; W.W. Jones and H.D. Chapman (1956). Changes in phosphorus in an irrigated soil during 28 years of differential fertilization. Soil Sci. 82: 295-306.

Rolston, D.E.; R.S. Rauschkolb and D.L. Hoffman (1975). Infiltration of organic phosphate compounds in soil, Soil Sci. Soc. Am. Proc., 39: 1089- I 094.

SAS Institute Inc. (1988). SAS User's guide. Statistical Analysis Institute.Inc., Cary, NC. 1674 P.

Singh, B.B. and J.P. Jones (1976). Phosphorus sorption and desorption characteristic of soil as affected by organic residues. Soil Sci. Soc. Am. J. 40: 389-394.

Soil Survey Staff (1994). Key to soil Taxonomy, USDA, Sixth Edition, Washington, D. C.

Steel, R.G.D. and G.H. Torrie (1982). Principles and procedures of statistics. A Biometrical Approach. Mc Graw-Hill Book Co, 625

U.S. Salinity Laboratory Staff (1954). Diagnosis and improvement of saline and alkali soils. USDA Agric. Handb. 60. U.S. Government Printing Office, Washington, D.C.

Watanabe, F.S. and S.R. Olsen (1965). Test of an ascorbic acid method for determining phosphorus in water and $\mathrm{NaHCO}_{3}$ extracts from soil. Soil Sci. Soc. Am. Proc. 29: 677-678. 


\section{الملخص العربي}

\section{العلاقه بين الفوسفور المتيسر والاسمدة العضوية المضافه في الاراضى الجيرية}

$$
\text { سعيد عباس تُمَّمَ السيد }
$$

اسمـدة عضـويه وكنتيجـة لـذلك فقـد استخخلص مستوى مرتفـع مـن

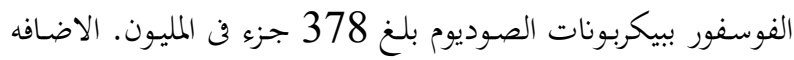

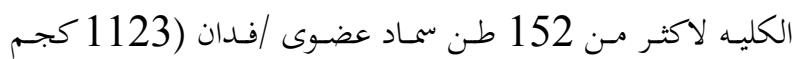

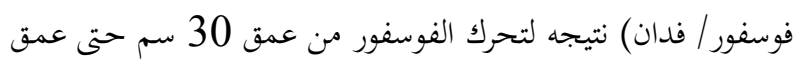

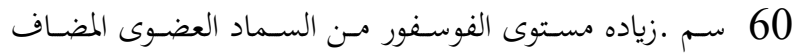
والمستخلص ببيكربونات الصوديوم كانت غير متحركه واضحه وجليه عند عمق صفر سم حتى عمق30 سم لملدة ستة اعوام بعد اضافة الاسمده العضويه حيث توقفت. اضافة 165 كجم فوسفور / فـدان على صورة سوبر الفوسفات

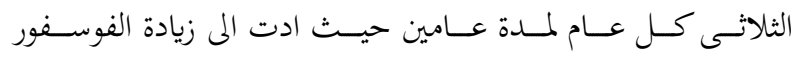
المستخلص ببيكربونات الصوديوم عن الكنترول بمقدار 12 جزء في المليون(نوفمبر، 2011). وعلى العكس من ذلك فان اضافة 141

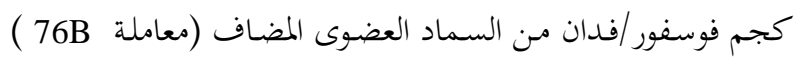

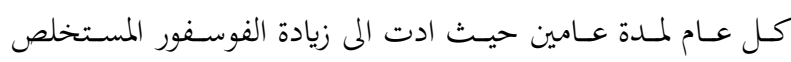

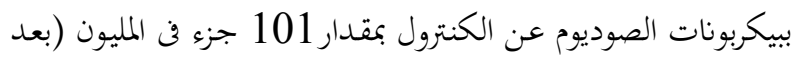
(الحصاد في عام 2007).
الهـدف مـن هـــه الدراسـة هـى قيـاس المتبقـى مـن الفوسـفور

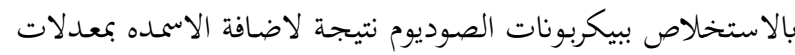

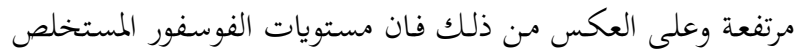

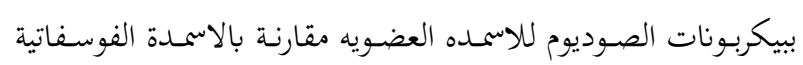

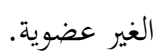

عند اضافة الفوسفور الغير عضوى بمعدل 206 كجم/ فدان كل عام لمدة عامين فان الفوسفور المستخلص بييكربونات الصوديوم يزداد

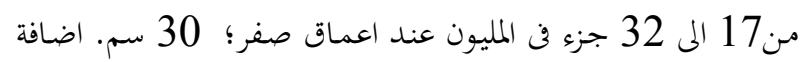

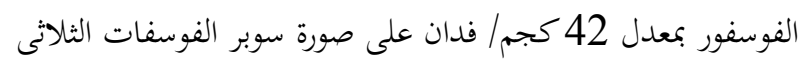
كل عام لمدة عامين قبل زراعة السبانخ(سبتمبر - اكتوبر) كان مؤثرا

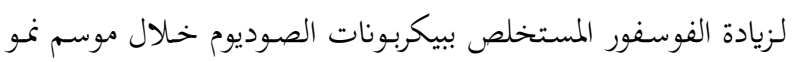

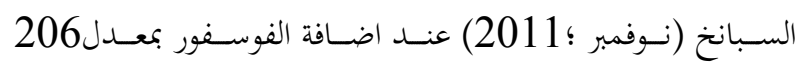
كجم/فدان في مايو او يونية كل عام لمدة عامين.

اضافة الفوسفور بمعدلات مرتفعه (2245 كجم/فدان)على صورة 